\title{
ARCHI-MIMESIS AS A DESIGN DOCTRINE
}

\author{
Özgür DEMIRKAN \\ Giresun University, Turkey \\ ozgur.demirkan@giresun.edu.tr \\ https://orcid.org/0000-0001-5430-1018 \\ Ayhan USTA \\ İstanbul Kültür University, Turkey \\ ayhanu@iku.edu.tr \\ https://orcid.org/0000-0002-9647-2576 \\ Emre ENGIN \\ Avrasya University, Turkey \\ emrengin@hotmail.com \\ https://orcid.org/0000-0002-2685-2717
}

\begin{abstract}
This study was based on a discussion of the relationship between mimesis and architectural design. Mimesis was accepted as one of the oldest and most basic concepts of artistic and literary efforts, a method to learn and produce a representation of reality from ancient periods to today. However, mimesis is not simply used as imitation, even in ancient periods. Mimesis has a strong relationship with various parameters like the physical material reality of the world, the era, the things the era brings, and the worldview, knowledge, and experience of the designer. In this context, this study is based on the theorem of the internalization of the objective world in the designing process and the mimetic approach in the designing process by including individual approaches in the creation process. To test this theorem, a workshop, conceptualized as "Archi-Mimesis," and accepting mimesis as creative designing doctrine, was organized. We describe Archi-Mimesis as mimesis or re-representation of the architecture, which is different from other nature-based methods like biomimetic, through the interface of mimetic methods maintained by considering reality through the creativity of architectural design and innovation oriented structure.
\end{abstract}

Keywords: Mimesis, Archi-Mimesis, Spatial Experience, Workshop

\section{BİR TASARIM ÖĞRETISİ OLARAK ARCHİ-MIMESİS}

\section{Öz}

$\mathrm{Bu}$ çalışma; mimesis ve mimari tasarım arasındaki ilişkinin varlığının tartışılması üzerine temellendirilmiştir. Mimesis, antik dönemden günümüze gerçekliğin temsili, öğrenmenin ve üretmenin yöntemi olarak sanatsal ve yazınsal kuramların en eski ve en temel kavramlarından birisi kabul edilmiştir. Ancak antik dönemde bile sadece taklit etmek anlamında kullanılmayan mimesis; bir tarafta dünyanın maddesel gerçekliğiyle diğer taraftan da üretenin dünya görüşü, bilgisi ve deneyimi, zaman ve zamanın getirdikleri gibi çeşitli parametrelerle güçlü bir ilişkiye sahiptir. Bu bağlamda yapılan çalışmanın önermesi; tasarlama sürecinde nesnel dünyanın içselleştirmesi ve bireysel yaklaşımların yaratma sürecine dahil edilmesinin aslında tasarlama deneyiminde mimetik bir yaklaşım içerdiğidir. $\mathrm{Bu}$ önermenin sınanması amacıyla 'Archi-Mimesis' olarak kavramsallaştırılan ve mimesisin yaratıcı bir tasarlama öğretisi olarak kabul edildiği bir workshop etkinliği düzenlenmiştir. Archi-MİMESİS; 
mimari tasarımın yaratıcılığa ve yeniliğe odaklı yapısı ile bir gerçekliğe bağlı kalınarak sürdürülen mimetik yöntemlerin arayüzünde ancak biomimesis gibi doğayı referans alan yöntemlerden farklı olarak mimarinin kendisinin yeniden temsili ya da mimesis olarak tanımlanmıştır.

Anahtar Kelimeler: Mimesis, Archi-Mimesis, Mekansal Deneyim, Workshop

\section{INTRODUCTION}

The Turkish Language Society explains mimesis as imitation, emulation, or mimicry, and the Britannica Dictionary explains it as the main rule of creating art but new art, not copying. Mimesis is used conceptually in various areas from production in different art disciplines to human behavior and beliefs, and it creates new meanings and objectives according to every new area to which it belongs. From a notion of the ancient period until today, it has developed conceptually in a wide and comprehensive manner; however, it maintains its original conceptual consistency. In this context, it has been associated with many subjects and disciplines from conscious or unconscious production to ethical and moral problems, lifestyles of different societies in different periods, and evaluation of art. However, discussing mimesis in architecture and architectural design requires opinions differing from the conceptual expansion that rhetoric, the theater, cultural identity, social identity, or today's common concept of mimesis presents. The design process is related to variable parameters which include introduction to architectural design, problem solving, design improvement, ending the designing process, and a lot of mental activities such as creativity guide this process. Parameters such as the needs program, the physical context, typological data, and the architect's or the culture's style of perception, and the architect's worldview affect the designing process (Demirkan, 2010).

However, mimesis has strong relationship with various parameters like the material reality of the world, and the worldview, knowledge and experience of the designer, the era, and the things era brings. Thus, the architectural design process basically includes the mimetic approach, and it enables understanding through metaphors forming the shape and the depth of the study at the end of the designing process.

Within this context, the metaphoric relationships between nature, modern technology, and the architectural paradigm and architectural design determine the architectural design process. Libeskind pointed out the ambiguous and tense relationship between German and Jewish cultures in the Holocaust Museum 'Between the Lines' and followed a mimetic style between this tense relationship and his project. Rem Koolhaas's project (Figure 2), the 'Zeebrugge Sea Ferry Terminal', reminding the viewer of a space helmet in old science-fiction comics, is considered mimetic similarity (Heynen, 2011). Hence, mimesis is a way to recreate material, conceptual, figural reality by using different methods such as imitating, emulating, adapting, replicating, or getting inspiration. That is why every architectural study, shaped at the end of the designing process, is a representation of the previous one (Figure 1, 2).

With the ideas mentioned above in mind, a workshop was organized where students could use mimesis in their own designing processes as a creative designing doctrine and develop different designing strategies. During this workshop, 'Archi-Mimesis' was described as mimesis or re-representation of the architecture, which is different from other nature-based methods like the biomimetic, through the interface of mimetic methods maintained by considering a reality with the creativity of architectural design and innovation-oriented structure.

In the study conducted by the Department of Interior Architecture at the Eurasian University, a process was experienced which focused on the structures and reality seen as reflections of the modernism movement, samples of which can be seen around the world, throughout Anatolia, and standing on the K.T.U campus. Thus, students were expected to gain an alternative point of view for their designing methods and complete plastic and spatial experiences based on the existence of architecture with creative representation, in other words, 'Archi-Mimesis'. 

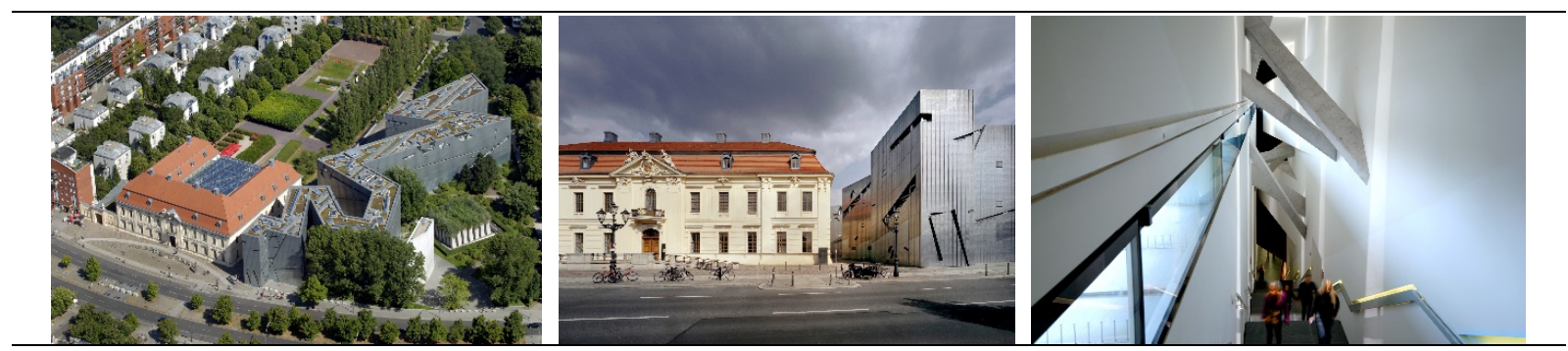

Figure 1. Daniel Libeskind, Jewish Museum (https://libeskind.com/work/jewish-museum-berlin/)

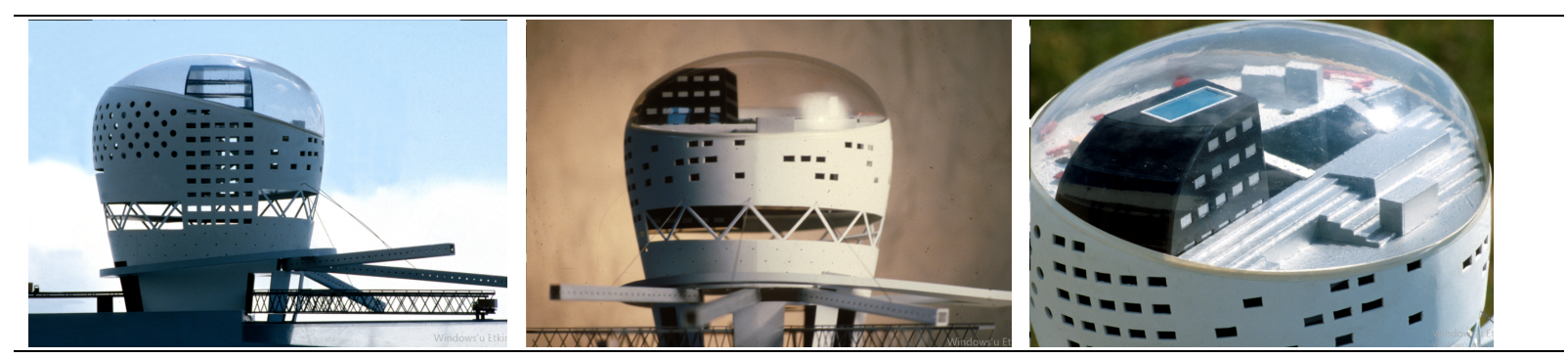

Figure 2. Rem Koolhas, Zeebrugge-Sea Terminal (http://oma.eu/projects/zeebrugge-sea-terminal)

\section{MIMESIS AS A DESIGNING DOCTRINE}

Mimesis is not used only for imitation, even in ancient periods. It has deeper meaning that explains many similarities and the equality of forms, from visual similarities between the reality and the idea to behavioral emulation and from metaphysical to aesthetic (Halliwell, 2002). Nature, including reality and beauty, is representative of everything in the world we live in, such as human behavior, ideas, and work. Thus, mimesis does not only mean copied a superficial copy of the visual but also imitation which is used to explain an event or incident (Potolsky, 2006). Beyond inferring one meaning and definition, mimesis is a representative way formed by some parameters, such as emulating in different contexts and with different meanings, reality, identity, getting inspiration, repeating, and imitating.

Mimesis is accepted as a way to learn and create. In fact, mimesis was suggested as "representative of nature" by Plato and Aristotle, but mimesis as a method of creation, was a basic point of disagreement between the two philosophers. Plato thought mimesis to be an imitation of reality which is dangerous and potential harmful, whereas Aristotle thought mimesis to be an innate aspect of human nature with its inner rules and effects. Plato's mimesis was conceptualized as a violent and irrational practice with extreme emotions whereas, Aristotle's mimesis was conceptualized as a rational and acceptable practice (Potolsky, 2006). Thus, Aristotle's mimesis is a representation method with which the unknown can be discovered, designed, and produced rather than a knowledge transferring tool. Even though it is developed largely by poets and rhetoricians, it is used as a method of production in different disciplines. It is a method through whish artists can understand the difference between the past and today, separate from the understanding his/her own natural and cultural environment, and so to create a structure in order to explain cultural evolution.

Moreover, it is a basis for education and a method to describe the advantages and restrictions of innovations (Ackerman, 2002). Within this context, conceptual consistency of mimesis still continues to be valid since ancient times. It has been developed as a common language and a representation of truth over its semantic entirety which it managed to protect, even in different disciplines.

On the other hand, architectural designing studios and design schools, dating back to the mentor system of the Ecole des Beaux Arts and Bauhaus, present a doctrine of design in which mimesis is consciously or unconsciously used as a design method. These institutions support the activity of mimesis as a representation in the designing process by discovering the unknown especially at the 
beginning of the architectural designing process or, during the process, increasing the alternatives and enriching points of view. A design process structured on learning by doing strengthens the relationship between the creative designing process and mimesis. As an introduction to design, it can be studied in this regard, which has become a common practice in design studios, and includes searching, analyzing, discussing similar architectural samples stylistically and functionally, and evaluating geometry of these samples. As Tanyeli suggested (2002), basically, the design process means choosing free images and combining them to form an entirety, either similar to the original or re-shaped. Thus, the design, structure, work, or product formed at the end of the designing process is a new representation of the previous one. It is both difference that aims to resemble and resemblance that aims to become different (Figure 3, 4).

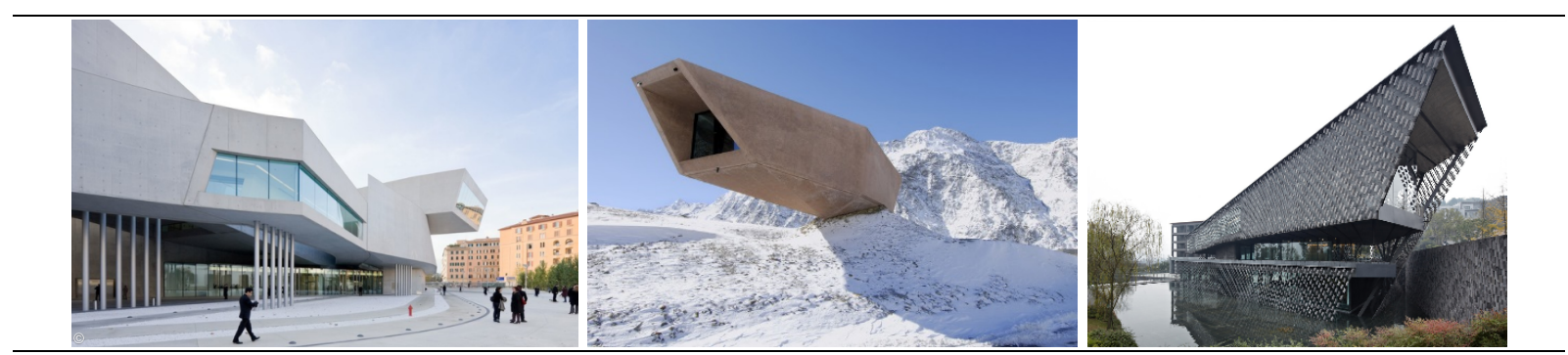

Figure 3. Zaha Hadid, 'MAXXI Museum'; Werner Tscholl, 'The Timmelsjoch Experience'; Kengo Kuma, 'Xinjin Zhi Museum' (https://www.archdaily.com/)
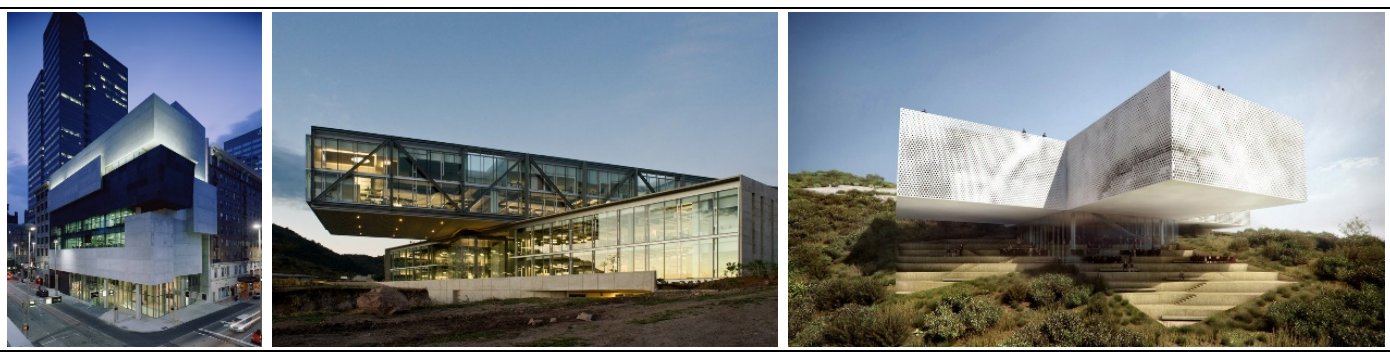

Figure 4. Zaha Hadid, 'Rosenthal Contemporary Art Museum'; KMD Architects, 'Cinepolis,' BIG 'New Tamayo Museum' (https://www.archdaily.com/)

\section{CASE STUDY: ARCHI-MIMESIS AS A DESIGN DOCTRINE}

Archi-Mimesis, organized as a workshop, aims to reproduce a structured environment or existing architectural reality with a creative design process. Archi-Mimesis, different from methods that reference nature such as biomimicry, is accepted as the source of production and learning for the architecture's inner parameters; mimesis is accepted as representation of this architectural reality. Archi-Mimesis is based on architectural structures on the K.T.U campus where representations of modernism movement are located. The KTU campus was built according to a winning design by the team of Nihar Guner and Mustafa Polatoglu of a national project contest, one of whose jury members was the famous architect Sedat Hakki Eldem. Structures by architects such as Dogan Tekeli, Sami Sisa, Erkut Sahinbas, reflecting the spirit of the period and the reality of modern architecture, were built on the campus thanks to contests organized in recent years. In this context, the KTU campus is original and known for its architectural reality thanks to distinguished samples of modern architecture and the original relationship of the structures. As explained below, the Archi-Mimesis study, conducted with volunteer students, followed these processes: definition, experiencing the spatial properties and plasticity of the structures in the campus area, design, and evaluation.

\section{Definition}

The concepts of mimesis, creativity, representation, architectural image, experiencing were discussed with the participants. What parameters direct the designing process; how they are analyzed; and the relationship between mimesis and architectural reality and designing process were examined through discussion of the concepts. Volunteers were asked to think about architectural reality as emulation, 
learning, adaptation and/or source implementation source, and to recognize Archi-Mimesis in their own design processes.

\section{Experiencing}

After recognizing Archi-Mimesis in all discussions, volunteers were taken to the K.T.U campus area. They were asked to experience and photograph the campus where the contest winning structure and Dogan Tekeli's structures stand, including the Ataturk Cultural Centre, the rectory building, the library, the electrical and computer engineering buildings, and the mechanical engineering building. In this process, volunteers were expected to experience an adventure by questioning what and how existing reality is being represented and what and who are represented. Volunteers got together after individual tours and were encouraged to share their observations about the architectural structures. The aim of this activity was to show that the volunteer participants could have different experiences and infer different meanings and representations with their individual approaches and then verbally share their experiences about the architectural structures. During the process of sharing their experiences, it was observed that volunteers share architectural structures and their experiences over concepts such as representation, representation tools and relationship between the representation and the area, arguments of modern architecture, architectural reality, emulation, and imitation. After these steps, the Archi-Mimesis attendees were asked to share their spatial experience using photographs and their observations on a digital platform and to create a visual storage with the photographs (Figure 5).
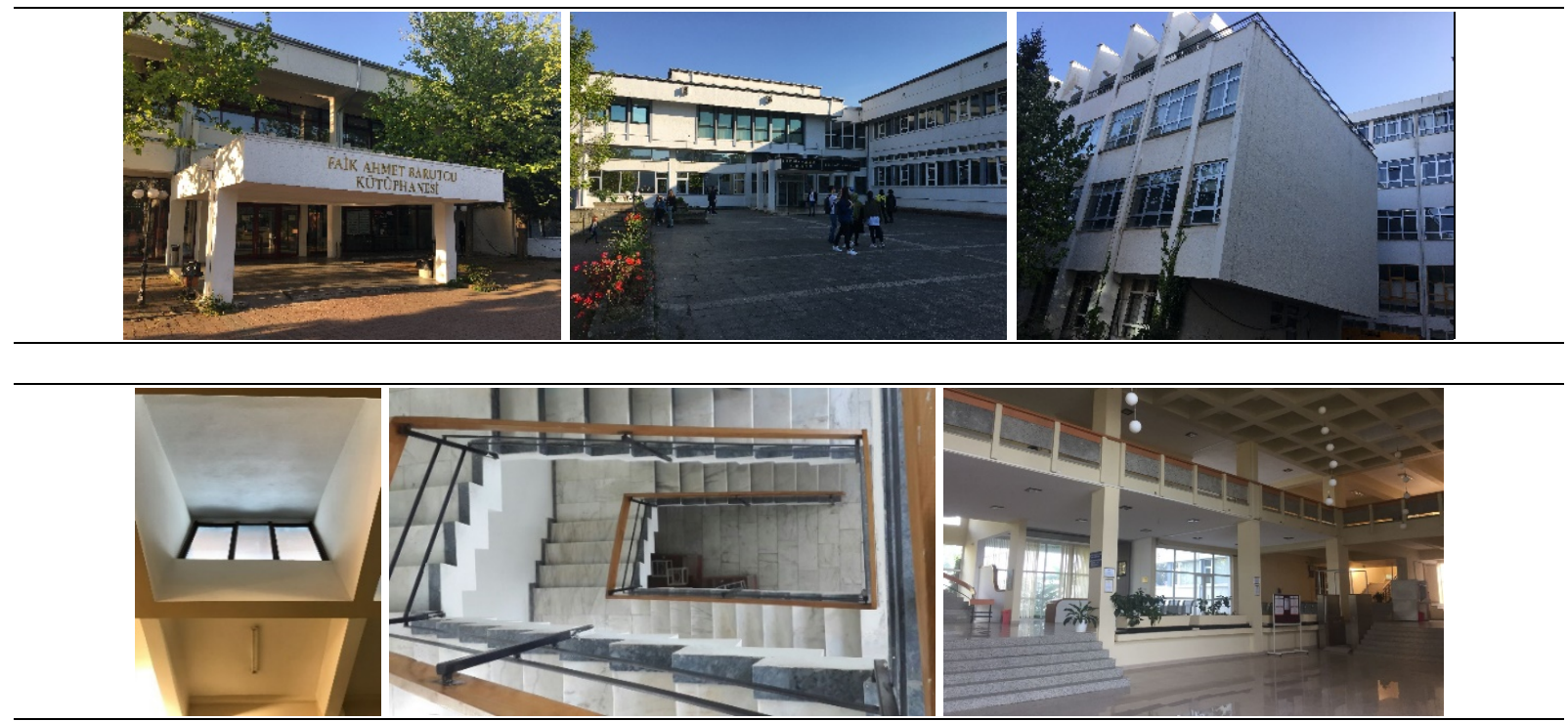

Figure 5. Photographs consisting of visual storage and students' spatial experience of the photographs

\section{Designing}

After experiencing the architectural reality, attendees, gathered around a table, were asked to divide into groups of six and to design an 'urban hub' by using their spatial experiences in an architecture design studio. Students were left alone and were given an interactive discussion environment with which to share their experiences with the other members of the group in a creative design event performed through functions that the attendees determined. The aim was to change the attendees' individual predictions into tools of representation by staying away from a formal design studio education. It was observed that students with their groupmates found alternative solutions, developed a representation with consensus through sketches, and detailed it as an 'urban hub' through the functions of a design studio ritual in this process. 

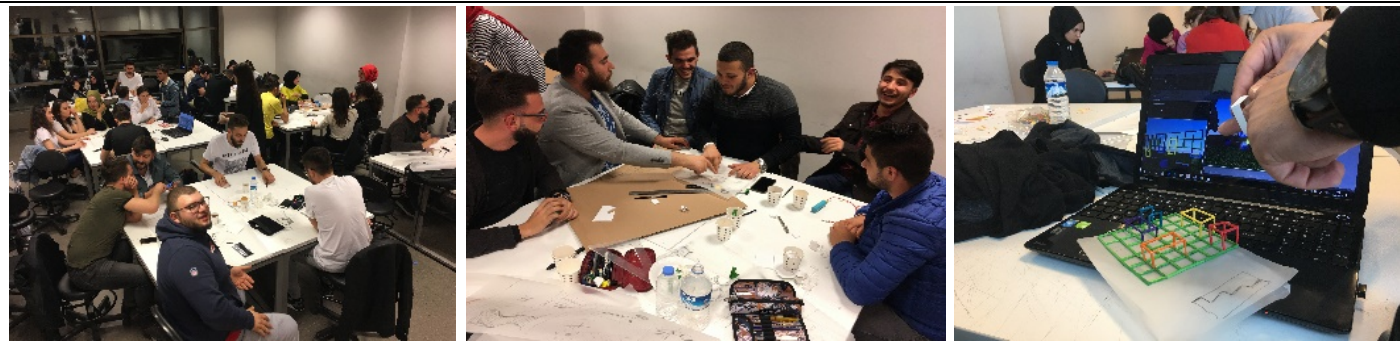

Figure 6. Design studio and attendees' design process

\section{Evaluation}

It was ensured that the groups shared and evaluated representations produced and formed by reproducing architectural reality after the design process was performed with the help of sketches and models in the design studio. Towards the end of the Archi-Mimesis workshop, the contributions of the event at the beginning and at the end were evaluated as a design doctrine. The transformation of architectural or objective reality that attendees experienced was evaluated with individual perceptions and spatial experiences. Individual differences, in the sense of mimesis and modernism arguments, were evaluated through representations.

Table 1. Experienced environment and representation during Archi-Mimesis (I.GROUP)

\begin{tabular}{c|c}
\hline I.Study Group \\
$\begin{array}{c}\text { Architectural Reality: KTU Department of } \\
\text { Electrical/Electronic Engineering }\end{array}$ \\
$\begin{array}{c}\text { Urban Hub: produced by referencing coffered slab in KTU, } \\
\text { Department of Electric-Electronic; resting and reading area } \\
\text { can be used outdoors. }\end{array}$ \\
\hline
\end{tabular}

Table 2. Experienced environment and representation during Archi-Mimesis (II.GROUP)

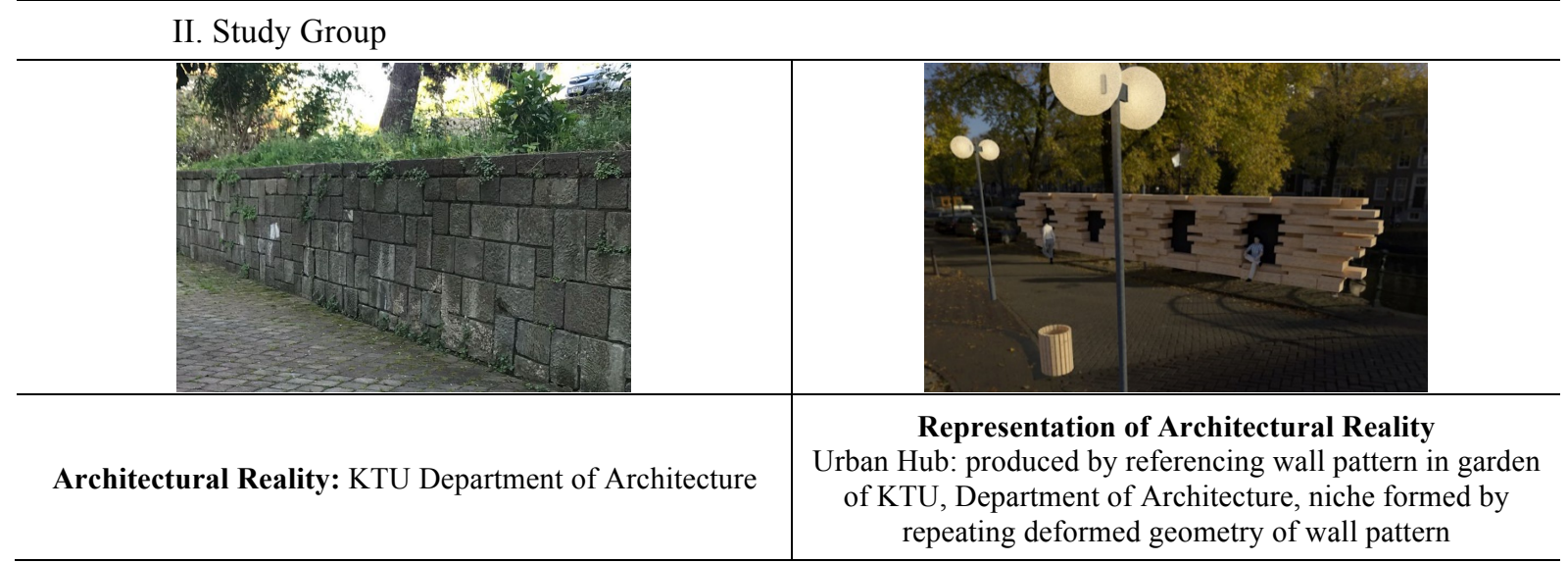


Table 3. Experienced environment and representation during Archi-Mimesis (III.GROUP)

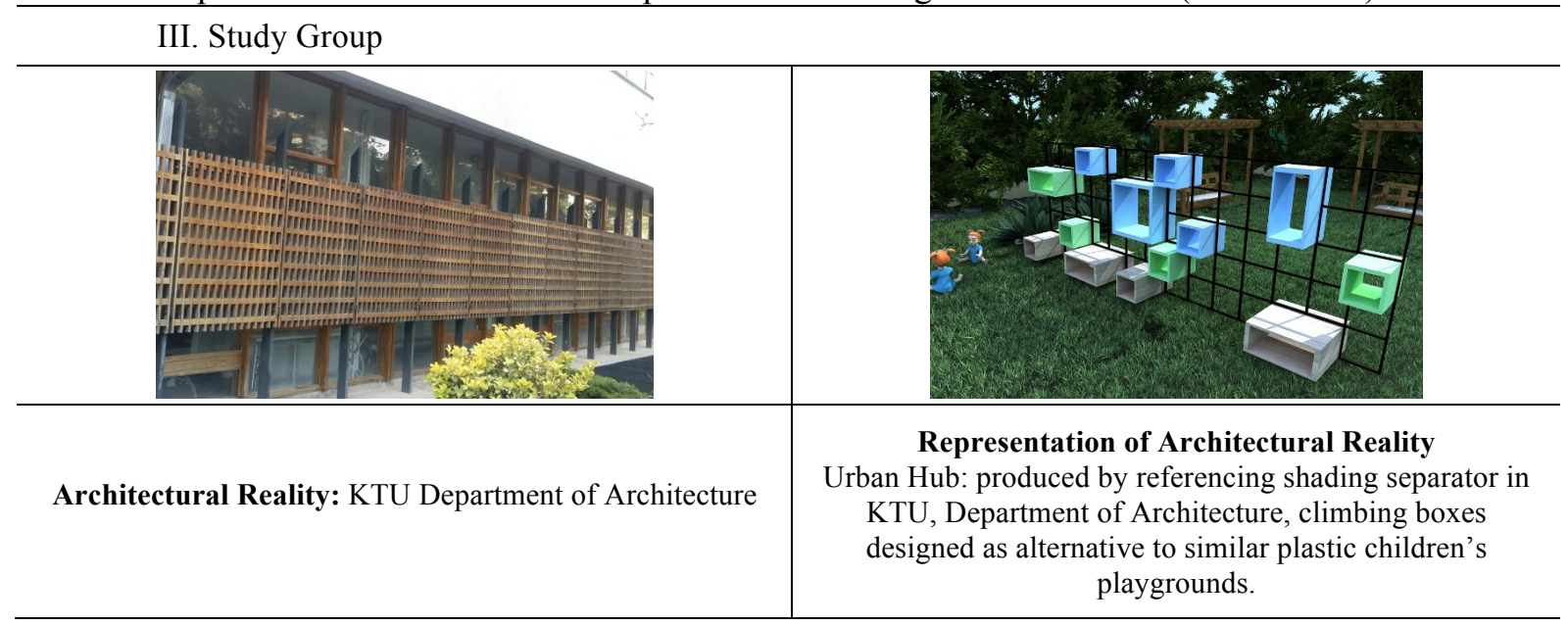

Table 4. Experienced environment and representation during Archi-Mimesis (IV.GROUP)

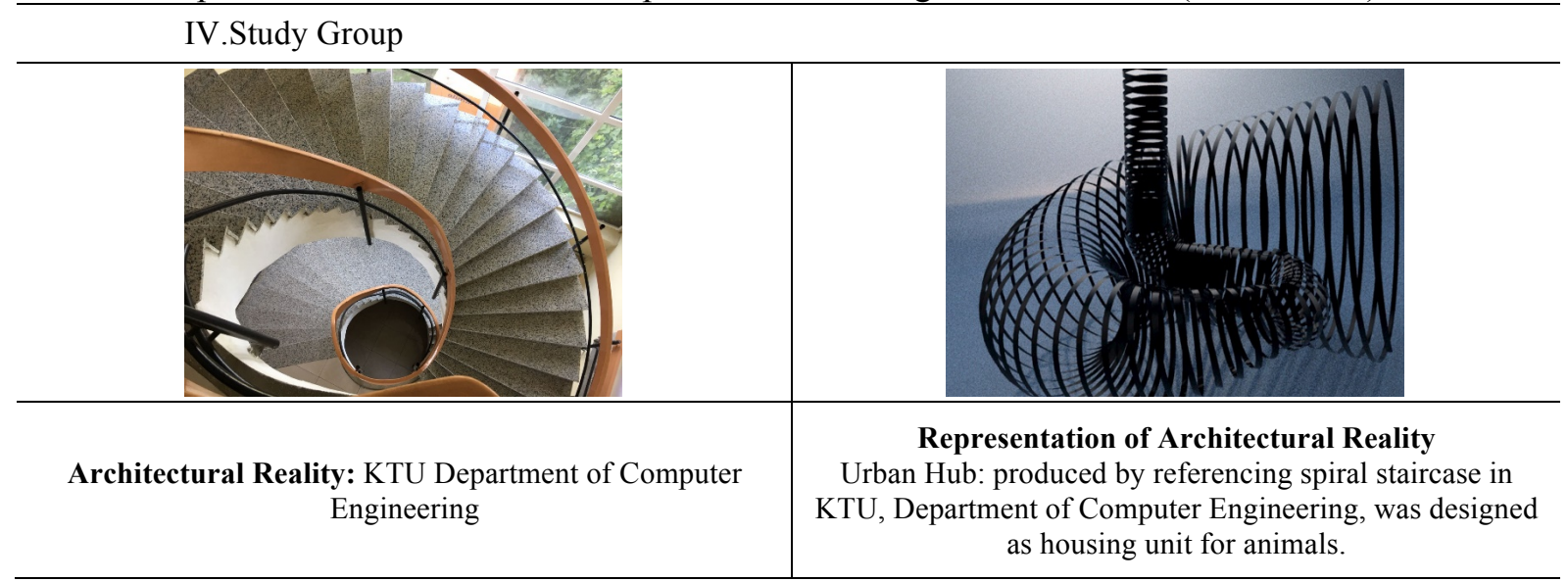

Table 5. Experienced environment and representation during Archi-Mimesis (V.GROUP)

\begin{tabular}{c|c}
\hline V.Study Group \\
Architectural Reality: KTU library garden wall
\end{tabular} \begin{tabular}{c}
$\begin{array}{c}\text { Urban Hub: designed by referencing KTU, library garden } \\
\text { wall and combination of plants on it, waiting lounge } \\
\text { module designed as transportation areas where passenger } \\
\text { circulation is excessive. }\end{array}$ \\
\hline
\end{tabular}




\section{CONCLUSION}

Archi-Mimesis is a combination of both the differences with the representation it tries to resemble and resemblances of the representation it tries to make different. Actually, every representation references, explains, and re-produces by repeating a previous architectural form, structure, and reality, as explained in this study. In brief, it multiplies reality, which it derives from, and re-creates it. It is the experiences, perceptions, cultures, and worldview of the designer and an interface of the meaning and existence of the designed reality. Thus, experiencing reality in the designing process distinguishes Archi-Mimesis as a creative design doctrine. Within this context, the achievements obtained after the experimental study with the attendees can be summarized as follows:

- The relationship between architecture and philosophy can be discussed through the concepts of design, form, replica, imitation, and mimesis,

- Statements of the modernism movement and its reflections in architecture can be discussed,

- The importance of designing by experiencing can be taught,

- $\quad$ During the design process, form-centered arguments can be ignored and developing alternative designing methods can be thought about freely,

- Learning is reflected through original architecture and the known structured area in design process,

- A design process is developed by noticing the architectural reality.

\section{REFERENCES}

Ackerman, J.S., (2002). Origins, Imitation, Conventions: Representation in the Visual Arts, MIT Press, Cambridge

Aristotales (2006). "Poetika” (M.Ö. 384 - 322), Çev. İsmail Tunal, İstanbul: Remzi Kitabevi

Demirkan, Ö. H., (2010). "Mimari Tasarımda Mimesis; Archiprix Projeleri Üzerinden Mimetik Bir Çözümleme Denemesi”, Yayınlanmamış Doktora Tezi, KTÜ.Fen Bilimleri Enstitüsü, Trabzon

Halliwell, S. (2002). "The Aesthetics of Mimesis: Ancient Texts and Modern Problems", Princeton University Press, New Jersey

Heynen, H. (2011). "Mimarlık ve Modernite; Bir Eleştiri", Çev. Nalan Bahçekapıll, İstanbul: Versus yayınlart

Platon (1992). “Devlet” (M.Ö. 386-367), Çev. S. Eyüboğlu, M. A. Cimcoz, Ístanbul: Remzi kitapevi

Potolsky, M. (2006). "Mimesis; The New Critical İdiom", Taylor\&Francis, New York

Reynolds, J., (1997). "Discourse on Art", New Heaven and London; Yale Universiy Press

Tanyeli, U., (2002). "Eskimiş bir kavramı yenileme Çă̆rısı/Taklit”, Arredamento Mimarlık Dergisi, Şubat, 2002, Istanbul 